\title{
Analisis Kebijakan Dana Desa untuk Pembangunan Kesehatan di Kabupaten Malinau dengan Pendekatan Segitiga Kebijakan
}

\author{
Santi Suarsih $^{1}$, Deni Kurniadi Sunjaya ${ }^{2}$, Elsa Pudji Setiawati², Guswan Wiwaha ${ }^{2}$, \\ Dewi Marhaeni Diah Herawati², Fedri R Rinawan ${ }^{2}$ \\ ${ }^{1}$ Dinas Kesehatan Kabupaten Malinau Prov Kalimantan Utara \\ ${ }^{2}$ Departemen Ilmu Kesehatan Masyarakat, Fakultas Kedokteran Universitas Padjadjaran
}

\begin{abstract}
Abstrak
Desa-desa di Kabupaten Malinau, Provinsi Kalimantan Utara mempunyai sumber dana untuk pembangunan kesehatan bersumber APBD dan APBN, namun masalah kesehatan di Kabupaten Malinau masih tinggi. Pada tahun 2015, AKB yaitu 25 per 1000 kelahiran hidup dan AKI yaitu 229 per 100.000 kelahiran hidup. Tujuan penelitian adalah untuk menganalisis kebijakan dana desa untuk pembangunan kesehatan di Kabupaten Malinau dari aspek konten, konteks, proses dan aktor. Desain penelitian kualitatif dengan pendekatan studi kasus di 4 desa. Penelitian dilakukan dengan wawancara mendalam terhadap 26 responden yang terlibat dalam kebijakan dana desa. Penelitian dilaksanakan pada bulan Oktober tahun 2016 sampai januari tahun 2017. Kondisi geografis, mata pencaharian, kekerabatan dan status desa memengaruhi perspektif masyarakat dalam melaksanakan pembangunan kesehatan. Tidak adanya regulasi dan petunjuk teknis mengenai pelaksanaan pembangunan kesehatan di desa menyebabkan ketimpangan pembangunan kesehatan di Kabupaten Malinau. Tenaga kesehatan harus mampu mengidentifikasi dan merumuskan masalah kesehatan di desa. Prinsip swakelola dalam pelaksanaan kebijakan dana desa meningkatkan ekonomi masyarakat dan mengurangi pengangguran. KebijakandanadesatelahdilaksanakandiKabupatenMalinau,tetapipemanfaatanuntukpembangunankesehatanbelum optimal. Diperlukan advokasi kepada pemerintah pusat untuk membuat regulasi alokasi dana desa untuk kesehatan. Tenagakesehatanharusproaktifdalamprosespenyusunankebijakanuntukmengungkitpembangunankesehatandidesa.
\end{abstract}

Kata Kunci : Dana Desa, Kabupaten Malinau, Segitiga analisis kebijakan

\section{The Analysis of Village Funds for Health Development in Malinau District by Triangle Policy Approach}

\begin{abstract}
Villages in Malinau District, North Borneo Province have source of funds for health development coming from the local budget and the state budget, yet health issues in Malinau is still high. By 2015, IMR is 25 per 1,000 live births and MMR is 229 per 100,000 live births. The purpose of this study is to analyze the policy of village funds for health development in Malinau in terms of content, context, processes and actors. Qualitative research with case study approach had been done in four villages. The study was conducted by giving in-depth interviews to 26 respondents involved in the village fund policy. The research was conducted in October 2016 to January 2017. The geographical condition, livelihood, kinship and the state of being a village affect people's perspectives in implementing health development. The absence of regulations and technical guidelines on the implementation of health development in the villages led to inequality of health development in Malinau District. Health personnel should be able to identify and formulate health problems in the villages. The principle of self management in the implementation of village fund policy improves peoples economy and reduces unemployment. Village fund policy has been implemented in Malinau District, however, the utilization for health development is no optimal. Advocacy on the central government is required to regulate the allocation of village funds in health sector. Health personnel must be pro active in the policy making process to lever the health development in villages.
\end{abstract}

Keywords : Malinau District, Triangle policy analysis, Village funds

Korespondensi:

Santi Suarsih, drg

Dinas Kesehatan Kabupaten Malinau Prov Kalimantan Utara

JI. Respen Tubu, Malinau Utara Kabupaten Malinau

Mobile : 08125403563

Email : anti_gozali@yahoo.co.id 


\section{Pendahuluan}

Pembangunan kesehatan merupakan upaya pemerintahuntuk memenuhi hak dasar masyarakat dalam memperoleh pelayanan kesehatan yang dilaksanakan secara profesional, berhasil guna dan memberikan manfaat yang sebesar-besarnya bagi peningkatan derajat kesehatan masyarakat yang optimal. ${ }^{1}$ Pembangunan kesehatan di daerah terpencil dan perbatasan seringkali mengalami hambatan karena kondisi geografis, kurangnya sarana transportasi, komunikasi serta adanya ketergantungan pada musim menjadikan biaya pembangunan kesehatan menjadi sangat mahal. ${ }^{2}$

Kabupaten Malinau terletak di wilayah Provinsi Kalimantan Utara, terdiri dari 15 kecamatan. Lima kecamatan berbatasan langsung dengan negara Malaysia dan dua kecamatan merupakan penyangga perbatasan yang hanya dapat terjangkau melalui transportasi sungai dan udara. Kondisi ini menuntut biaya yang tinggi dalam pelaksanaan pembangunan dalam rangka meningkatkan taraf hidup dan kesejahteraan masyarakat di wilayah Kabupaten Malinau., ${ }^{3,4}$

Upaya Pemerintah Kabupaten Malinau dalam pemerataan pembangunan adalah dengan menerapkan konsep pembangunan Gerakan Desa Membangun. Seluruh penyelenggaraan pemerintahan dan pembangunan didasarkan pada kepercayaan sepenuhnya kepada rakyat sebagai pemegang kedaulatan tertinggi yang harus menikmati kesejahteraan dan menempatkan masyarakat desa sebagai pelaku pembangunan. ${ }^{4}$ Pemerintah pusat pada saat ini mempunyai strategi Nawacita ketiga yaitu membangun Indonesia dari pinggiran dengan memperkuat daerahdaerah dan desa dalam kerangka NKRI. ${ }^{5}$ Hal ini diimplementasikan dengan adanya kebijakan dana desa yang diatur dengan Peraturan Pemerintah Nomor 22 tahun 2015 tentang dana desa yang bersumber dari APBN. Peraturan Menteri Desa, PDT dan Transmigrasi Nomor 22 tahun 2016 menyatakan bahwa prioritas penggunaan dana desa untuk bidang pembangunan desa dan pemberdayaan masyarakat desa.

Hasil penelitian di Kecamatan Malinau Kota menunjukkan bahwa meskipun desa mempunyai sumber dana untuk melaksanakan pembangunan kesehatan tetapi masalah kesehatan di Kecamatan Malinau Kota masih tinggi. Jumlah rata-rata dana yang dimiliki desa adalah 2,9 Milyar dan ratarata penggunaan dana desa untuk pembangunan kesehatan adalah 6,04 \%. Hal ini karena pemerintah desa lebih banyak membelanjakan dana desa untuk pembangunan di bidang non kesehatan dibandingkan untuk pembangunan kesehatan. Data kesehatan di Kecamatan Malinau Kota menunjukkan bahwa jumlah kematian bayi masih tinggi yaitu 4 orang; cakupan Rumah tangga ber PHBS 68,63 \% dan jumlah kasus Demam Berdarah yaitu 83 orang. ${ }^{3}$

Kebijakan dana desa diperuntukkan untuk pembangunan kesehatan, akan tetapi di tingkat desa di Kabupaten Malinau hanya sebagian kecil saja yang mengganggarkan dana desa untuk pembangunan kesehatan. Keadaan ini menunjukkan perlu adanya analisis kebijakan dana desa di Kabupaten Malinau. Pendekatan segitiga kebijakan digunakan untuk menganalisis kebijakan dana desa dengan mempertimbangkan konten, konteks, proses dan aktor kebijakan. ${ }^{6}$ Tujuan penelitian ini adalah menganalisis kebijakan dana desa untuk pembangunan kesehatan di Kabupaten Malinau dari aspek konten, konteks, proses dan aktor.

\section{Metode}

Desain penelitian adalah kualitatif dengan menggunakan pendekatan studi kasus. Karakteristik dari strategi studi kasus pada penelitian kualitatif yaitu Bounded, Embedded, Multivariate, Multimethod, Multidiciplinary dan Multisite. Data yang dikumpulkan dalam penelitian ini diperoleh dari hasil wawancara mendalam dengan menggunakan pedoman pertanyaan. Alat yang digunakan dalam penelitian ini adalah alat perekam, kamera dan alat tulis. Terdapat empat komponen yang dianalisis pada penelitian ini yaitu konteks, konten, proses dan aktor.

Subjek penelitian yaitu 26 orang yang telibat dalam kebijakan dana desa. Enam belas orang yang mewakili 4 desa di Kabupaten Malinau berdasarkan kriteria Indeks Desa Membangun terdiri dari Desa Malinau Kota dengan status desa maju, Desa Malinau Seberang dengan status desa berkembang, Desa Malinau Hilir dengan status desa tertinggal, Desa Semengaris dengan status desa sangat tertinggal. Subyek terdiri dari Kepala Desa, Ketua Badan Permusyawaratan Desa (BPD), tenaga kesehatan Desa dan Ketua PKK Desa; empat orang terdiri dari Camat dan Kepala Puskesmas Malinau Kota dan Malinau Utara; serta enam orang wakil Pemerintah Daerah Kabupaten Malinau yang terlibat dalam kebijakan dana desa, terdiri dari Kabid Yankes Dinas Kesehatan, Kepala Bappeda, Sekretaris Badan Keuangan, Kepala Bidang BPMD, Kepala Bagian Tata Pemerintahan dan Kepala Sub. Bagian Perundang-undangan Bagian Hukum Pemerintah Daerah Kabupaten Malinau.

Kriteria inklusi yang dipilih pada penelitian kualitatif adalah subyek terpilih yang mewakili 4 desa di Kabupaten Malinau dan subyek terpilih 
yang mewakili SKPD yang terlibat dalam kebijakan dana desa. Kriteria eksklusi subjek yang dipilih yaitu subyek tidak dapat ditemui dan subyek tidak bersedia menjadi responden penelitian.

Penelitian dilaksanakan pada bulan Desember tahun 2016 sampai bulan Januari tahun 2017. Tempat penelitian adalah di Kabupaten Malinau, Provinsi Kalimantan Utara.

Analisis penelitian ini yaitu menggunakan metode kualitatif dengan analisis konten. Data hasil wawancara mendalam dianalisis melalui proses transkripsi, reduksi, coding dan kategorisasi. Penafsiran kode mencakup membandingkan frekuensi tema, mengidentifikasi tema dan menampilkan hubungan antara tema yang berbeda. Analisis tema berguna dalam menangkap kerumitan makna dalam data. Penelitian ini telah mendapatkan ethical approval dari Komite Etik Penelitian Kesehatan Fakultas Kedokteran Universitas Padjadjaran.

\section{Hasil}

Aspek Konten Pembangunan Kesehatan dalam Kebijakan Dana Desa; Sumber utama pendapatan desa yaitu dari APBD Kabupaten Malinau melalui dana program Gerakan Desa Membangun dan dari APBN melalui dana desa yang digulirkan mulai tahun 2015. Dana desa APBN dari tahun ke tahun mengalami peningkatan. Menteri Desa ketika melakukan kunjungan kerja ke Kabupaten Malinau pada tahun 2016 menyatakan bahwa besaran dana desa pada tahun 2018 akan mencapai 2 sampai 3 Milyar untuk tiap desa.

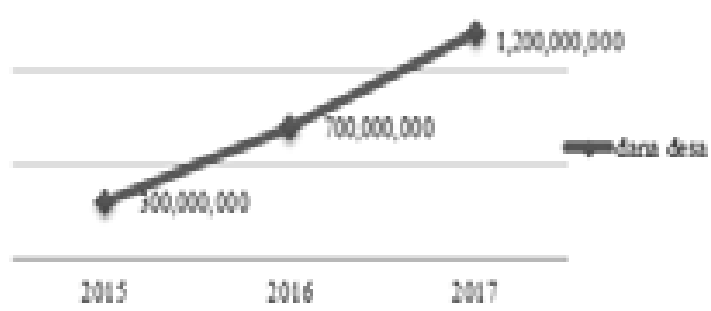

\section{Gambar 1 Grafik Dana Desa dari APBN di Kabupaten Malinau Tahun 2015-2017}

Penggunaan anggaran desa untuk pembangunan kesehatan di Kabupaten Malinau mengacu kepada beberapa Peraturan Menteri Desa, PDT dan Transmigrasi mengenai penetapan prioritas penggunaan dana desa dan Keputusan Bupati Malinau Nomor 137-1/K223/2014 tentang petunjuk teknis penyerahan urusan pemerintah kabupaten ke desa. Peraturan Menteri Desa,
PDT dan Transmigrasi ini digunakan sebagai acuan dalam perencanaan kegiatan-kegiatan tidak langsung bidang kesehatan, sedangkan Keputusan Bupati mengatur tentang penyerahan urusan langsung bidang kesehatan ke desa, digunakan sebagai acuan dalam merencanakan kegiatan-kegiatan langsung bidang kesehatan.

Penggunaan dana desa baik yang bersumber dari APBN maupun APBD sejalan dalam penggunaannya, dan sumber dana ini membantu desa dalam melaksanakan pembangunan dan pemberdayaan masyarakat desa, akan tetapi ada yang berbeda dalam hal penggunaannya. Penggunaan dana desa APBN lebih ketat aturannya dan setiap tahun berubah prioritasnya. Pada tahun 2015 penggunaan dana desa APBN cenderung untuk pembangunan infrastruktur, sedangkan untuk tahun 2016 cenderung ke pembangunan ekonomi yaitu dalam hal penguatan BUM desa. Untuk penggunaan dana desa APBD lebih fleksibel, kegiatan tergantung dari usulan masyarakat, hanya tidak boleh lepas dari koridor empat pilar pembangunan Kabupaten Malinau yaitu pemerintahan, ekonomi kerakyatan, pembangunan infrastruktur dan pengembangan SDM.

Aspek Konteks Kebijakan Dana Desa di Kabupaten Malinau; Konteks dalam analisis kebijakan dana desa adalah karakteristik desa. Masyarakat Kabupaten Malinau terdiri dari berbagai macam suku, mata pencaharian, pola kekerabatan dan budaya. Mayoritas suku di Kabupaten Malinau adalah suku Dayak yang terdiri dari suku Dayak Kenya, Lundayeh, Tidung dan Bulungan. Hubungan kekerabatan di antara masyarakat sangat erat dan memiliki rasa kebersamaan yang tinggi. Budaya gotongroyong masih melekat erat disetiap individu masyarakat. Hal ini terllihat di semua desa kecuali di Desa Malinau Kota yang masyarakatnya sudah campuran antara penduduk asli dan suku pendatang, seperti suku Jawa, Sunda, Toraja, Bugis dan Timor. Mata pencaharian penduduk pada umumnya adalah petani dan nelayan.

Permasalahan pembangunan kesehatan yang terjadi dalam konteks karakteristik desa-desa di Kabupaten Malinau adalah kemajemukan masyarakat yang tinggi.

Kemajemukan masyarakat yang tinggi menyebabkan kompleksitas permasalahan juga tinggi. Kondisi ini membutuhkan dana yang lebih tinggi untuk melaksanakan pembangunan terutama untuk Desa Malinau Kota. Masalah lainnya adalah kehidupan suku Dayak di wilayah terpencil yang masih menggantungkan hidupnya terhadap alam. Kondisi geografis desa-desa di Kabupaten Malinau yang pada umumnya adalah dataran rendah seperti di empat desa yang diteliti 
mempunyai resiko tinggi mengalami banjir ketika musim hujan. Terdapat desa-desa yang seringkali mendapat banjir kiriman dari daerah hulu Kabupaten Malinau. Mata pencaharian masyarakat desa di Kabupaten Malinau pada umumnya adalah petani dan nelayan. Hal ini berdampak pada pola belanja masyarakat dalam menggunakan anggaran desanya untuk pembangunan.

Aspek Proses Penyusunan Kebijakan Dana Desa di Kabupaten Malinau; Pada proses kebijakan dana desa, kekuasaan tertinggi ada di masyarakat karena semua usulan muncul dari masyarakat. Konsep pembangunan yang dipakai di Kabupaten Malinau adalah perencanaan pembangunan partisipatif dengan melibatkan masyarakat dalam setiap prosesnya. Tahap yang paling berpengaruh pada proses kebijakan dana desa adalah tahap formulasi kebijakan. Tahap formulasi kebijakan di desa merupakan kegiatan musyawarah perencanaan pembangunan (Musrenbang). Proses Musrenbang di Kabupaten Malinau terdiri dari beberapa tahap yaitu Pra Musrenbang Desa/Musrenbang RT, Musrenbang Desa, Musrenbang Kecamatan dan Musrenbang Kabupaten.

Hasil dari Musrenbang desa adalah dokumen RAPBDes. Dokumen RAPBDes sebelum disahkan menjadi APBDes akan dievaluasi terlebih dahulu oleh tim evaluasi APBDes dari Pemerintah Daerah Kabupaten Malinau. Apabila ada ketidaksesuaian dokumen hasil musrenbang dengan RAPBDes yang diajukan, maka tim evaluasi RAPBDes akan meminta alasan yang harus dapat dipertanggungjawabkan oleh desa beserta berita acara perubahan hasil Musrenbang tersebut. Apabila telah sesuai maka RAPBDes bisa disahkan menjadi APBdes.

Pelaksanaan kebijakan dana desa didasarkan pada prinsip swakelola. Pemantauan dan evaluasi pelaksanaan penggunaan anggaran desa diselenggarakan oleh Bupati dengan pelimpahan tugas kepada Badan Pemberdayaan Masyarakat Desa (BPMD). Di tingkat desa, Pemerintah desa dan BPD melaksanakan tugas pemantauan dan evaluasi penggunaan anggaran desa yang dibahas dalam musyawarah desa dengan format laporan pertanggungjawaban yang diserahkan kepada Bagian Tata Pemerintahan.

Rendahnya alokasi anggaran desa untuk pembangunan kesehatan dipengaruhi oleh faktor politik. Pembangunan kesehatan untuk investasi jangka panjang tidak berwujud sehingga bukan hal yang menguntungkan untuk kepentingan politik. Terdapatnya ketidaksesuaian informasi tenaga kesehatan, pemerintah desa dengan SKPD terkait kebijakan dana desa berpengaruh dalam proses kebijakan dana desa. Hal ini seringkali menyebabkan tenaga kesehatan pesimis bahwa pembiayaan untuk kesehatan sudah dipatok sehingga tidak bisa menambah alokasi pembiayaan.

Aktor Kebijakan Dana Desa Untuk Pembangunan Kesehatan; Aktor kebijakan dana desa memiliki peranan penting dalam setiap proses kebijakan. Aktor kebijakan dana desa di KabupatenMalinauterbagimenjadi:1.Masyarakat terdiri dari Ketua RT, tokoh masyarakat, tokoh adat, tokoh wanita, tokoh pemuda, tokoh agama dan tenaga pendidikan. 2. Pemerintah Desa terdiri dari Kepala Desa, Sekretaris Desa, Kepala urusan Desa, Kepala Seksi Desa, staf desa, Ketua PKK Desa, LPM, Lembaga Adat dan BPD. 3. Kecamatan terdiri dari Camat, Sekretaris Camat dan Kepala-Kepala Seksi di Kecamatan. 4.PemerintahDaerahKabupaten terdiridariSKPD terkait kebijakan dana desa yaitu Bappeda, BPMD, Badan Keuangan, Bagian Tata Pemerintahan, Bagian Hukum, LP3MD dan tenaga pendamping desa. 5. Sektor kesehatan terdiri dari Dinas Kesehatan, tenaga kesehatan Puskesmas, tenaga kesehatan Pustu/desa dan kader-kader kesehatan.

\section{Pembahasan}

Di Kabupaten Malinau Provinsi Kalimantan Utara, sebelum tahun 2011 Pemerintah Daerah Kabupaten Malinau telah menggulirkan dana pembangunan untuk desa melalui program Gerakan Desa Mandiri. Hasil pembangunan pada saat itu masih belum dirasakan masyarakat karena dominasi pemerintah daerah kabupaten masih tinggi dalam proses pembangunan. Pada tahun 2012, Pemerintah Daerah Kabupaten Malinau mencanangkan konsep pembangunan yang berbeda yaitu program Gerakan Desa Membangun. Konsep program Gerakan Desa Membangun berbanding terbalik dengan program sebelumnya. Program ini menganut pendekatan bottom up dengan perencanaan pembangunan partisipatif. ${ }^{4,7}$ Pada tahun 2015, dengan adanya program pemerintah pusat dalam rangka mewujudkan nawacita ketiga maka pemerintah pusat menyalurkan dana ke setiap desa di Indonesia. ${ }^{5}$ Kebijakan dana desa yang digulirkan oleh Pemerintah Pusat membawa "angin segar" untuk desa-desa di seluruh Indonesia dalam melakukan pembangunan. "Angin segar" itu lebih dirasakan oleh masyarakat desa di Kabupaten Malinau, karena dengan adanya dana desa dari pemerintah pusat, maka sumber anggaran pendapatan desa menjadi dua, yaitu dari APBN dan APBD Kabupaten.

Besaran dana desa yang bersumber APBN ditetapkan dengan memperhatikan faktor jumlah 
penduduk, angka kemiskinan, luas wilayah dan tingkat kesulitan geografis. Jumlah dana desa yang meningkat setiap tahunnya membuktikan keseriusan pemerintah dalam melaksanakan pembangunan sesuai dengan Nawacita ketiga yaitu dengan memberikan modal pendanaan kepada desa untuk melaksanakan pembangunan. Desa sebagai ujung tombak pembangunan di Indonesia dapat melaksanakan kegiatan pembangunan yang bertujuan untuk mencapai masyarakat desa yang sejahtera. ${ }^{5}$ Masyarakat desa yang sejahtera dapat dilihat dari status desa berdasarkan komponen Indeks Desa Membangun (IDM). Untuk mewujudkan IDM yang tinggi maka salah satu komponen yang harus dibangun adalah komponen di bidang kesehatan. Kecenderungan pembangunan kesehatan yang dilakukan adalah pembangunan fisik. Hal ini karena desa-desa di Kabupaten Malinau masih memerlukan pembangunan infastruktur kesehatan. Pemerintah desa menganggap bahwa pembangunan dapat dipertanggungjawabkan apabila hasil pembangunan itu berwujud dan dapat dilihat, tidak seperti kegiatan-kegiatan promosi kesehatan. Hal ini menyebabkan desa tidak mempunyai keberanian dalam mengalokasikan dana untuk pembangunan kesehatan yang tidak berwujud. Hal ini serupa dengan hasil studi dokumen di tiga kecamatan di NTT bahwa hasil Musrenbangcam tahun 2010 menyatakan bahwa jenis-jenis usulan kegiatan bidang kesehatan yang diakomodir sebagian besar adalah usulan kegiatan yang bersifat fisik dan hanya sedikit yang bersifat non fisik. ${ }^{8}$ Alokasi anggaran desa untuk pembangunan kesehatan dipengaruhi juga oleh faktor politik. Pembangunan kesehatan untuk investasi jangka panjang tidak berwujud sehingga bukan hal yang menguntungkan bagi kepentingan politik. Terdapatnya ketidaksesuaian informasi tenaga kesehatan, pemerintah desa dengan SKPD terkait penggunaan anggaran desa untuk pembangunan berpengaruh dalam proses kebijakan dana desa.

Tidak adanya "payung" hukum yang mengatur tentang alokasi pembangunan kesehatan bersumber anggaran desa menyebabkan kegiatan pembangunan kesehatan kurang. Salah satu upaya untuk meningkatkan alokasi anggaran desa untuk pembangunan kesehatan adalah melakukan advokasi kepada Pemerintah agar membuat regulasi dalam menetapkan besaran dana untuk pembangunan di bidang kesehatan dari APBDes. Selama ini pemerintah hanya mengatur alokasi dana kesehatan melalui Undang-Undang Nomor 36 Tahun 2009 yang menyatakan bahwa Pemerintah Daerah harus mengalokasikan dana untuk sektor kesehatan yaitu $10 \%$ dari APBD di luar gaji. ${ }^{9}{ }^{10}$ Harapan lainnya adalah adanya petunjuk teknis mengenai pelaksanaan untuk pembangunan di bidang kesehatan. Hal ini dimaksudkan agar penggunaan dana desa tidak hanya untuk pembangunan infrastruktur kesehatan akan tetapi mulai memikirkan mengenai pembangunan investasi dalam meningkatkan kualitas kesehatan seperti peningkatan gizi masyarakat.

Konteks mengacu kepada faktor sistematis yang memiliki pengaruh terhadap kebijakan dana desa yaitu karakteristik desa. Karakteristik dan latar belakang masyarakat masing-masing desa berbeda, baik dalam latar belakang pekerjaan, etnis, pola pemukiman, dan kondisi geografis. Kondisi geografis mempengaruhi tingkat pembangunan di Kabupaten Malinau dikarenakan mahalnya biaya transportasi dari ibukota kabupaten ke kecamatan-kecamatan di Kabupaten Malinau. Hal ini mengakibatkan tingginya biaya pembangunan untuk desa-desa yang tidak bisa dijangkau transportasi darat. ${ }^{6}$

Karakteristik desa membentuk pola pikir masing-masing warga masyarakat. Perspektif masyarakat dalam melihat permasalahan dan cara membuat solusinya merupakan hal yang penting dalam dalam proses Musrenbang di desa. Upaya dalam meningkatkan alokasi anggaran desa untuk pembangunan kesehatan adalah dengan memahami kondisi masyarakat yang tinggal di desa. ${ }^{4}$ Kemajemukan masyarakat yang tinggi seperti di Desa Malinau Kota yang penduduknya terdiri dari beberapa suku menyebabkan kompleksitas permasalahan juga tinggi. Dengan banyaknya permasalahan yang timbul maka dana yang dibutuhkan oleh desa dalam melaksanakan pembangunan juga tinggi. Mayoritas penduduk di Kabupaten Malinau adalah etnis Dayak. Hubungan kekerabatan pada suku Dayak sangat tinggi. Biasanya penduduk satu desa mempunyai hubungan keluarga. Untuk meningkatkan pembangunan kesehatan di desa, tenaga kesehatan bisa memberikan pemahaman bahwa semua anggota masyarakat di desa itu adalah keluarga. Pemahaman ini menimbulkan kemauan masyarakat untuk memberikan persetujuan mengenai kegiatan-kegiatan untuk peningkatan kesehatan keluarga. Dibutuhkan kemampuan tenaga kesehatan dalam memberikan pemahan dan menjual program kesehatan kepada masyarakat. Kehidupan suku Dayak yang masih tergantung kepada alam menyebabkan pola pemukiman suku Dayak di tempat terpencil sulit terjangkau oleh tenaga kesehatan. Kondisi ini membutuhkan dana yang besar agar pembangunan kesehatan dapat dinikmati oleh masyarakat.

Tahap yang paling berpengaruh pada proses kebijakan dana desa adalah kegiatan musyawarah perencanaan pembangunan (Musrenbang). ${ }^{7}$ 
Proses Musrenbang di Kabupaten Malinau terdiri dari beberapa tahap yaitu Pra Musrenbang Desa/ Musrenbang RT, Musrenbang Desa, Musrenbang Kecamatan dan Musrenbang Kabupaten. Tenaga kesehatan desa harus mampu mengidentifikasi masalah, merumuskan permasalahan kesehatan di desa tersebut mulai dari menginvetarisir sumber daya yang ada sampai kendala yang dihadapi. ${ }^{11}$ Kehadiran tenaga kesehatan dalam setiap proses perencanaan pembangunan di desa, menentukan muncul tidaknya kegiatan pembangunan kesehatan di dalam APBDes. Pada proses Musrenbang, tenaga kesehatan tidak boleh apatis, harus mampu meyakinkan peserta Musrenbang dengan cara mengedepankan program kesehatan yang nyata. ${ }^{4,}{ }^{12}$ Pemerintah desa seringkali mementingkan pembangunan yang menampakkan wujud fisiknya agar dapat diperlihatkan kepada tingkat pemerintah yang lebih tinggi dan masyarakat bahwa pembangunan didesanyaberhasil. DokumenRAPBDes sebelum disahkan menjadi APBDes akan dievaluasi terlebih dahulu oleh tim evaluasi APBDes dari Pemerintah Daerah Kabupaten Malinau. Apabila ada ketidaksesuaian dokumen hasil musrenbang dengan RAPBDes yang diajukan, maka tim evaluasi RAPBDes akan meminta alasan yang harus dapat dipertanggungjawabkan oleh desa beserta berita acara perubahan hasil Musrenbang tersebut. Apabila telah sesuai maka RAPBDes bisa disahkan menjadi APBdes.

Prinsip swakelola dalam pelaksanaan kebijakan dana desa menyebabkan peningkatan ekonomi masyarakat dan mengurangi pengangguran di desa. Hal ini dikarenakan kegiatan pembangunan di desa dilaksanakan sendiri oleh masyarakat. Untuk kegiatan-kegiatan pembangunan yang tidak memerlukan keahlian teknis seperti semenisasi dilaksanakan sendiri oleh masyarakat sehingga upah pekerja kembali lagi untuk masyarakat desa itu sendiri dan hal ini merupakan salah satu nilai positif dari dana desa. Peningkatan ekonomi akan meningkatkan status kemajuan dan kemandirian desa berdasarkan Indeks Desa Membangun. ${ }^{13}$

Evaluasiyangdilaksanakanhanyamenyangkut masalah kemajuan fisik pembangunan berupa laporan pertanggungjawaban keuangan. Evaluasi belum sampai pada adanya dokumen yang menunjukkan proses evaluasi secara keseluruhan. Pemantauan dan pengawasan pembangunan desa dilakukan oleh masyarakat desa yang hasilnya dilaporkan kepada Pemerintah Desa dan BPD. Akan tetapi di Kabupaten Malinau tahap ini belum berjalan dengan baik, dikarenakan masyarakat seringkali hanya sekedar melihat ada atau tidaknya pembangunan tanpa mengetahui rincian kegiatan pembangunan yang seharusnya

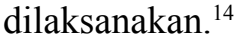

Aktor kebijakan dana desa memiliki peranan penting dalam setiap proses kebijakan. ${ }^{6}$ Kepala Desa merupakan pemegang kekuasaan tertinggi di desa. Visi dan misi Kepala Desa menentukan arah pembangunan desa yang tercermin dalam kegiatan-kegiatan perencanaan pembangunan desa. Aparat desa merupakan pelaksana kebijakan di desa. Aparat desa yang mampu bekerja dengan baik akan dapat menjalankan kebijakan sesuai prosedur sehingga pembangunan di desa akan berjalan sesuai dengan yang diinginkan, akan tetapi seringkali pemilihan aparat desa diwarnai oleh faktor politik dan kekerabatan. Faktor-faktor ini akan menghambat proses pembangunan di desa kecuali aparat desa tersebut memang memiliki kemampuan bekerja secara profesional. Rendahnya pembangunan kesehatan disebabkan pemerintah desa menganggap bahwa yang bertanggung jawab untuk pembangunan kesehatan adalah Dinas Kesehatan dan Puskesmas

Untuk melaksanakan pembangunan di desa, diperlukan sumberdaya manusia yang bukan hanya sanggup bekerja keras, tetapi mampu bekerja profesional dan memiliki kemampuan yang handal. Tenaga kesehatan harus mampu membangun relasi informal dengan pemerintah desa. Upaya untuk mengungkit dana desa terkait dengan sistem perencanaan Musrenbang, seharusnya ada penguatan di tingkat RT dengan memanfaatkan kader-kader. Diusahakan di setiap bidang atau program ada kader kesehatan. Kader-kader ini dberikan arahan, pemahaman tentang kegiatan kesehatan mana yang butuh pembiayaan sehingga usulan itu nanti muncul dari RT. Permasalahan alokasi anggaran desa untuk pembangunan kesehatan yang rendah terutama diakibatkan oleh incapacity sektor kesehatan dalam memanfaatkan peluang anggaran desa. Tenaga kesehatan di desa sebagai pelaku pembangunan kesehatan di desa masih memiliki keterbatasan dalam manajerial dasar untuk mengidentifikasi kebutuhan dan masalah dasar, memobilisasi sumber daya, merencanakan kegiatan dan sebagainya. ${ }^{11}$ Tugas pihak Puskesmas dan tenaga kesehatan di desa adalah untuk mengadvokasi desa dan memanfaatkan peluang anggaran desa tersebut.

Hasil penelitian ini masih memiliki keterbatasan, diantaranya yaitu pemanfaatan waktu ketika wawancara belum maksimal dan terdapat Kepala SKPD yang tidak dapat ditemui dikarenakan keperluan lain sehingga memengaruhiketajamaninformasiyangdiperoleh.

Kebijakan dana desa telah dijalankan di Kabupaten Malinau, akan tetapi pelaksanaannya untuk pembangunan kesehatan masih belum optimal. Hal ini disebabkan oleh beberapa hal, 
yaitu 1) Kondisi geografis, faktor ekonomi, sosial dan budaya serta status desa memengaruhi perspektif masyarakat dalam melaksanakan proses pembangunan kesehatan di desa; 2) Pemanfaatan dana desa untuk pembangunan kesehatan masih rendah; 3) Tidak adanya petunjuk teknis mengenai pelaksanaan pembangunan kesehatan di desa menyebabkan ketimpangan pembangunan kesehatan di beberapa desa di Kabupaten Malinau; dan 4) Permasalahan utama rendahnya alokasi anggaran desa untuk pembangunan kesehatan di Kabupaten Malinau adalah incapacity sektor kesehatan dalam memanfaatkan peluang anggaran desa.

Penelitian perlu diperluas ke daerah-daerah lain di Indonesia untuk mendapatkan kelengkapan konsep dan hasil penelitian ini dapat dijadikan bahan oleh pemerintah daerah untuk menyusun perencanaan pembangunan kesehatan di tingkat desa.

\section{Daftar Pustaka}

1. Hendriyanto JH, Juanita. Evaluasi Kebijakan Berobat Gratis Di Kabupaten Tanjung Jabung Timur Provinsi Jambi. Jurnal Kebijakan Kesehatan Indonesia. 2013;02(02 Juni):71-6.

2. Luti I, Basri MH, Lazuardi L. Kebijakan Pemerintah Daerah Dalam Meningkatkan Sistem Rujukan Kesehatan Daerah Kepulauan Di Kabupaten Lingga Provinsi Kepulauan Riau. Kebijakan Kesehatan Indonesia. 2012;1(1).

3. Profil Dinas Kesehatan Kabupaten Malinau Tahun 2015.

4. Hartono A. Manajemen Partisipasi dalam Gerakan Desa Membangun di Kabupaten Malinau Provinsi Kalimantan Utara. Samarinda: RV Pustaka Horizon; 2016.

5. Visi, Misi dan Program Aksi Jokowi JK.
http://kpu.go.id/koleksigambar/VISI MISI Jokowi-JK.pdf. 2014.

6. Buse K, Mays N, Walt G. Making Health Policy: London School of Hygiene and Tropical Medicine; 2005.

7. Himang AM. Perencanaan Partisipatif Dalam Musrenbang Kampung ( Studi Perbandingan di Kampung Laham dan Kampung Danum Paroy Kec. Laham Kab. Mahakam Ulu. Pemerintahan Integratif. 2015;3(3):371-88.

8. Dodo D, Trisnantoro L, Riyanto S. Analisis Pembiayaan Program Kesehatan Ibu dan Anak Bersumber Pemerintah Dengan Pendekatan Health Account. Kebijakan Kesehatan Indonesia. 2012;01(01):13-23.

9. Laksmiarti, Nugraheni. Analisis Kebijakan Pembiayaan Kesehatan di Kabupaten Kepulauan Aru. Badan Litbang Kesehatan Kemenkes RI. 2013.

10. FITRA S, Foundation TA. Kinerja Pengelolaan Anggaran Daerah 2009: Study di 41 Kabupaten/Kota di Indonesia. Jakarta: 2010.

11. Symond D. Penentuan prioritas masalah kesehatan dan prioritas jenis intervensi kegiatan dalam pelayanan kesehatan di suatu wilayah. Jurnal Kesehatan Masyarakat.7(No.2):94-100.

12. Imro'atin E, Laily N. Partisipasi Masyarakat dalam Perencanaan Pembangunan Partisipatif. Kebijakan dan Manajemen Publik. 2015;3 (Nomor 2).

13. Peraturan Menteri Desa, Pembangunan Daerah Tertinggal dan Transmigrasi Republik Indonesia Nomor 2 Tahun 2016 tentang Indeks Desa Membangun.

14. Kus Winarno MH, Deni Kurniadi Sunjaya. Evaluasi Kebijakan Pembangunan Puskesmas Pembantu di Propinsi Kalimantan Tengah. Jurnal Kebijakan Kesehatan Indonesia. 2013(02):86-94. 